\title{
Application Perspectives of the Leaf Area Index (LAI) Estimated by the Hemiview System in Forestry
}

\author{
Nerijus Sidabras*, Algirdas Augustaitis \\ Aleksandras Stulginskas University, Faculty of Forest Sciences and Ecology, Kaunas dstr. Lithuania
}

\begin{abstract}
Leaf area index (LAI) is widely used to describe the main characteristics of forest stands such as cover intensity at different forest levels from moss to tree as well as main stand dendrometric parameters. Hemispherical canopy photograph was used for analyzing quality and quantity of coniferous forest in Aukstaitija national park. Different sampling systems from single plots to aggregating them into stands allowed assessing significance of LAI detected by the HemiView system in forestry without special preparation. The obtained data revealed that the use of hemispheric photograph for LAI estimation in multi-aged and multi-layered mature and over mature pine and spruce stands was rather problematic. Only cover intensity of understory vegetation (grasses and mosses) was reflected best. In pure pine stands LAI also significantly reflected spatial changes in cover intensity of shrubs, grasses and mosses levels and in addition - spatial changes in main dendrometric stand parameters. Key findings - significant relationships between LAI detected in November and pine needle litterfall over September-October. It allowed detecting significance of LAI in mass balance of the main nutritional and contaminant components calculations. LAI increase by $1 \mathrm{~m}^{2} \mathrm{~m}^{-2}$ increased total litterfall amount by $1.7 \mathrm{tha}^{-1}$ in a pure mature pine forest. The obtained results indicated good perspectives of LAI detected by HemiView system in forestry even without special their preparation.
\end{abstract}

Key words: LAI by HemiView system, dendrometric parameters, cover intensity, litterfall.

\section{Introduction}

Understanding dynamics of leaf area index (LAI) at ecosystem scale is artificial for evaluating and modeling the response of vegetation to environmental variability and change (Ryu et al., 2010). Leaf area index (LAI) quantifies the amount of leaf area bearing by a tree or whole stand normalized by the unit of crown projected or the whole stand ground area (Norman and Campbell, 1989). It is one of the most important structural characteristics of a tree foliage (Pokorny and Stojnič, 2012) in controlling many biological and physical processes in plant canopies (Chen et al., 1997). It offers a possibility for ecologists to estimate the importance of both the leaf surface area and foliar weight as factors affecting many tree and stand-level processes and functions such as photosynthesis, gas exchange, growth, stand productivity and canopy dynamics (Arias et al., 2007) for testing and improving phenology models, evaluating remote-sensing-derived LAI products, and quantifying forest structures in rapidly changing environments (Ryu et al., 2010).

LAI can be estimated by employing variable experimental methods that can be simply classified into four groups: (1) direct methods, (2) semi-direct methods, (3) indirect methods, (4) subjectiveevaluation methods (Norman and Campbell, 1989). In the presented study LAI was detected by employing an indirect method based on the hemispherical photograpy. This method has been used since the 1960s in forest ecology (Chianucci and Cutini, 2012, Evans and Coombe, 1959). However, significant obstacles involving film cameras (i.e., lack of software, time-consumption, acquisition and processing procedures), film hemispherical photography has been progressively forsaken (Breda, 2003). Today, a hemispherical photography provides a permanent record and is therefore a valuable information source for a position, size, density and distribution of canopy gaps. This enables to capture the species-, site- and age-related differences in canopy architecture, based on high attenuation and contrast between features within the photo (sky versus canopy) (Jonckheere et al, 2004; Rich, 1990).

Advances in digital photographic technology have led to renewal of interest in photographic methods to quantify forest canopy indirectly. So far, hemispherical photography is widely used of several photographic techniques (Chianucci and Cutini, 2012). Despite uncertainties due to image acquisition and processing steps, digital photography holds a great promise for estimating forest canopy properties, on account of its speed, ready availability and lowcost, which enables widespread use of the method (Chen et al., 1997).

\footnotetext{
* Corresponding Author's email: nerijussidabras09@gmail.com
} 
Therefore, in the present study, we set out to see whether LAI detected using hemispheric photography could be used for spatial assessment of forest structure and response to its abundance of understory vegetation. In order to meet this aim, the following research tasks were carried out:

- to estimate the capacity of LAI to describe tree structure in coniferous forest;

- estimate the capacity of LAI to describe cover intensity of understory vegetation in coniferous forest;

- detect real pine needles area index in LAI comparing data on indirect and semi-direct estimation;

- establish capacity of LAI detecting litterfall amount in pure even-aged pine stands;

- assess significance of LAI employing the HemiView system in forestry.

Obtained data could be used as a scientific basics investigating spatial changed parameters of pine forest ecosystem solving the most important recent problem - Scots pine stands sustainability under the pressure of global changes (Augustaitis, 2011, Mozgeris et al., 2011a, Pociene et al., 2011).

\section{Materials and Methods}

The variation in forest growth in relation to natural and anthropogenic factors is of main concern for researchers who study the impact of global changes on forest ecosystems (Augustaitis, 2011, Augustaitis et al., 2014). In this field the searches of indicators of forest condition become one of the greatest concerns. Simplicity in establishment and reliability of detected tree reaction are the main requirements for such indicators. Therefore, hemispheric photography is quite usually applied not only to detect leaf area index (LAI) or plant area index (PAI), but also cover intensity of tree canopy and understorey vegetation. Therefore, to confirm our hypothesis, we tried to examine the possibility of detected LAI by HemiView system to use describing the tree community (forest stand), their density and productivity as well as health and biodiversity and abundance (cover intensity) of understory vegetation. Based on the obtained results, we expect to evaluate the significance of indirectly detected LAI in research of forest sustainability under the pressures of global changes.

The study was carried out in the integrated monitoring station (coordinates latitude: $55.26^{\circ} \mathrm{N}$, longitude $26.04^{\circ} \mathrm{W}$, altitude: $159 \mathrm{~m}$ ) established in Aukstaitija National Park (ANP) located in the north-eastern part of Lithuania. The annual average temperature and precipitation are $5.5{ }^{\circ} \mathrm{C}$ and 650 $\mathrm{mm}$, respectively (Augustaitis et al., 2010a; 2010b). Coniferous forests aged approximately 60 (79 \%) prevail in ANP. However, there are some stands present that are over 200 years old. Therefore, the data on LAI and assessment of their significance are presented in the study distributed into two age groups: middle aged stands (age around 60 year) and mature and over matured pine stands (age more than 120 year).

A field survey of the sample plots was carried out during the measuring campaign at the end of July and beginning of August 2013. Forests of the Aukstaitija integrated monitoring station (IMS) basin were chosen as the main object to detect the significance of LAI estimating the cover intensity of understory vegetation and parameters of mixed coniferous stands. Multi-aged and multi-layered mature and over mature pine and spruce stands on haplic arenosol, transfering at lower places into albic and gleyic arenosol and into histosol (eutrophic deep peat soil) prevail in the catchment. Field activities at 47 Aukštaitija IMS permanent observation plots (Figure 1) were carried out employing the methodology of ICP Forests Monitoring (UN-ECE, 1994). a)

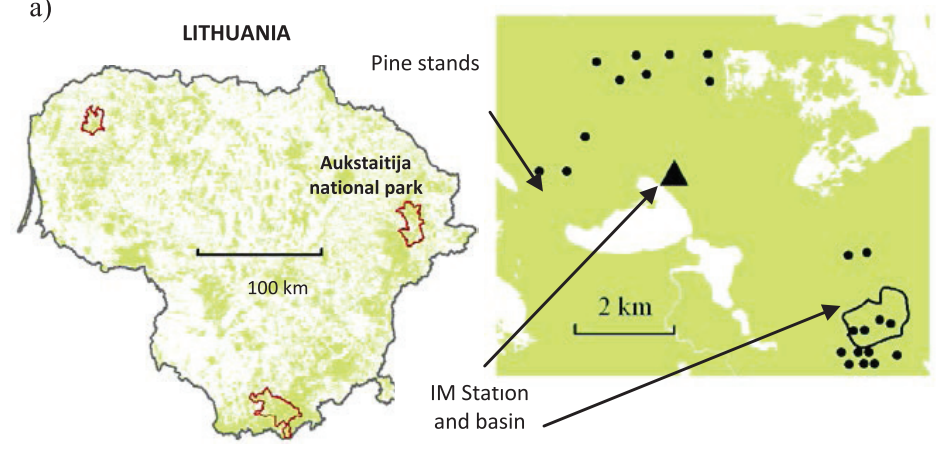

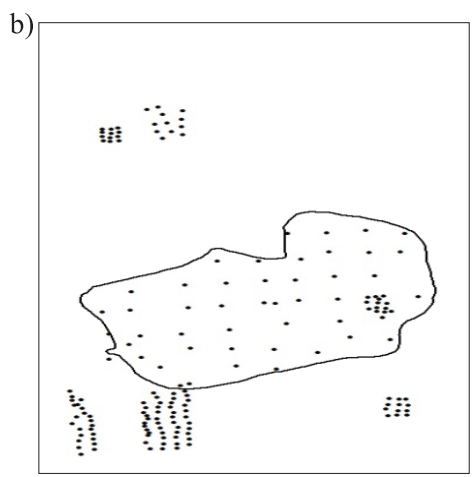

Figure 1. a) Location of Aukstaitijs NP, Integrated Monitoring Station ( $\boldsymbol{\Delta})$, b) its basin, permanent observation pine stands $(\bullet)$ and sample plots $(\circ \circ)$. 
To assess significance of LAI estimated by the HemiView system in pure even-aged pine forest, the investigations were carried out on 10 permanent observation stands, which were established at the beginning of 1980s (Figure 1). A three stage sampling pattern was used to establish these stands: (1) sampling of the research stands; (2) sampling of 12 circular plots within each considered research stand; (3) sampling of trees for more detailed measurements of tree stem and crown indicators, and tree ring analysis. 12 sample plots in each stand were distributed in a systematic way - according to a grid. The place of the first sample plot was chosen randomly. The area of circular sampling plots was determined to contain on average 15-20 trees, i.e., what made about 150-250 sample trees per stand. Tree stem diameter, height and crown defoliation was estimated on 120 permanent observation plots of 10 monitored stands according to ICP and our methodology (Augustaitis et al., 2010b; Augustaitis 2011; UN-ECE, 1994).

Herbaceous and moss species composition and abundance were recorded for each species according to the Braun-Blanquet method. The overall percentage of cover for each understorey vegetation layer (shrubs, herbs and mosses) was estimated. Tree species were assigned to different layers according to their heights (Marozas et al., 2014).

LAI or tree crown canopy was quantified by digital hemispherical photographs taken at the center of each plot using the equipment and software of Hemiview (Delta-T devices Ltd., Cambridge, UK). A selflevelling camera mounted on a tripod was positioned $1 \mathrm{~m}$ above the ground. The camera was oriented to magnetic north, and exposure and aperture were set according to the manufacturer's recommendations (Delta-T Devices Ltd., Cambridge, UK) (Marozas et al., 2014). To obtain high-quality, evenly exposed photographs, photos were taken when the sky was overcast. Photographs were analyzed using the Hemiview software. The image classification was performed manually using the threshold algorithm Hemiview according to the recommendations in the user manual. The research included some of the auxiliary indicators such as visible sky (VisSky), diffuse radiation above canopy (DifAb), diffuse radiation below canopy (DifBe), direct radiation above canopy (DirAb), direct radiation below canopy (DirBe), total radiation above canopy (TotAb), total radiation below canopy (TotBe) and ellipsoidal leaf angle distribution parameter (ELADP). For further data analyses, leaf area index (LAI) alone was used as a measure of light intensity (Anderson, 1964).

To detect pine needle area in total LAI, we used the direct estimation method, which was based on the long term litterfall data at Aukštaitija Integrated monitoring station. 5 pictures were made above 5 litterfall collectors in November 2013, when the fall of pine needles was over. The collectors were installed at evenly spaced intervals of $10 \mathrm{~m}$ along 50 $\mathrm{m}$ long transect crossing the stands from west to east (Chen et al., 1997). The square collectors made $1 \mathrm{~m}^{2}$ and were placed about $20 \mathrm{~cm}$ above the ground. The needles were dried at $70^{\circ} \mathrm{C}$ for $24 \mathrm{~h}$ and the total dry weight of all the needles was obtained. Scanned pine needles allowed detecting the area of one gramme air dry needles mass. Collected pine needles mass during September-October (main pine needles fall in Lithuania) of 5 collectors was computed into needle surface area. Mean value of 5 collectors enabled to detect the coefficient of transformation from mass to one site surface area, i.e., $1 \mathrm{~g}=44.9 \mathrm{~cm}^{2}$. LAI of surrounding pine trees was detected based on the presumption that the mass of fallen pine needles was two times lower than that in the crown. Therefore, needles area index of pines growing around the collectors had to be two times higher than the LAI of fallen needles.

Simple correlation analysis was employed to detect the significance of LAI detected by the HemiView system and dendrometric parameters of monitored stands as well as cover intensity of shrubs, grass and moss levels.

\section{Results and Discussion}

Leaf area index (LAI) is widely used to describe the photosynthetic and transpiration surface of plant canopies. LAI can be defined as the amount of leaf surface area per unit ground area, and has broad applications in ecophysiology, water balance modeling, and characterization of vegetationatmosphere interactions. Recently, many researchers have adopted the definition of LAI as half of the total leaf area per unit ground surface area, as opposed to the projected area, which does not work well for all leaf shapes. D.A. Sampson et al. revealed that indirect estimates of LAI did not correlate with allometric estimates for lodgepole pine, and correlated only weakly with litter-trap estimates (Sampson and Allen, 1995). Therefore, capacity of LAI detected by the indirect method using hemispheric photography was analyzed in mixed coniferous forest growing in catchment of Aukstaitija Integrated monitoring station and in pore even-aged pine stands growing in the vicinity of this station in Aukstaitija NP.

Significance of LAI in multi-aged mixture coniferous forest in Aukstaitija IMS basin. One of the main tasks of implementation of Integrated monitoring program is to estimate mass balance 


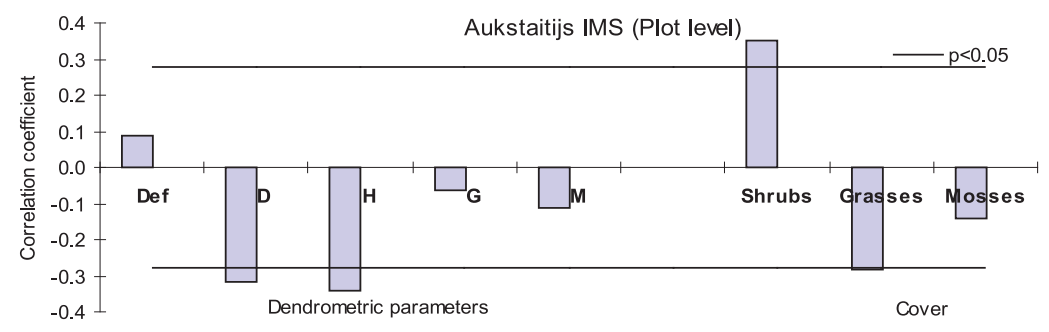

Figure 2. Relationship between LAI and dendrometric parameters, defoliation and cover intensity of understory vegetation of the mixed coniferous stands.

of the main nutritional sources as well as the main contaminants for the evaluation of forest sustainability under the pressures of global changes (Augustaitis et al., 2010a; Bringmark et al., 2012; Holmberg et al., 2012). Cover intensity of different plant levels in the stand is a key variable resulting in the transformation and sequestration of the chemical compounds in the forest ecosystem. Therefore, estimation of LAI on permanent observation plots could help to meet the key tasks of this ICP IM programme.

Detected LAI of multi-aged and multi-layered mature and over mature pine and spruce stands using hemispheric photography revealed indirect relationships with stand mean diameter and height, (Figure 2). These findings confirmed the state of knowledge in this field (Pokorny and Stojnič, 2012). However, no significant relationships were found between LAI and stand sum square basal area or volume. Correlative analysis between LAI and cover intensity of understory vegetation indicated direct effect of light intensity to cover intensity of grasses and mosses. High relationships between LAI and cover intensity of shrubs indicated that shrubs higher than $1 \mathrm{~m}$ have direct effect on LAI detected using hemispheric photography. These findings should be taken into account analyzing LAI capacity to describe the volume or biomass of a stand. Therefore, in stands with dense samplings the level reliability of LAI detected by HemiView system is also very limited.
Significance of LAI in even-aged pure pine forest in Aukstaitija NP. Correlative analysis of the dendrometric characteristics of monitored trees from permanent observation plots and all detected indices from hemispheric photography including LAI revealed rather different results in comparison with the data obtained at IMS. In pure pine stands LAI value demonstrated a significant relationship with density as well as volume of the monitored pine stands classified into two main age groups. Approximately $40 \%$ changeability of these parameters was explained by LAI. Mean value of tree diameter and height of pine stands did not result in changes in LAI, but only in stands attributed to younger stand group. In stands over 120 years old, LAI index explained about $50 \%$ variation in mean value of tree height on the level of sample plots (Figure 3). Mean data of monitored stands (mean value of 12 plots) revealed more significant relationships between mean value of stands LAI and their dendrometric parameters: first of all the sum of tree basal area and volume. This data confirm our hypothesis that LAI detected from hemispheric photography quite well reflect changes in main parameters of pore pine stands, however, it is only in case when stands are distributed according to their age. Obtained data revealed that with pine stand ageing, LAI did not demonstrate the tendency towards reduction in pore pine stands, what indicated other authors investigating LAI of the stands of other
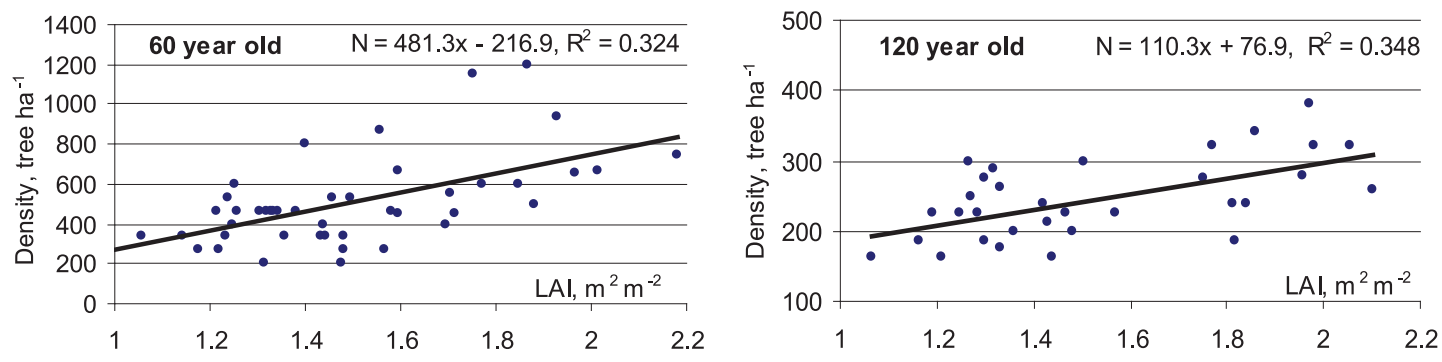

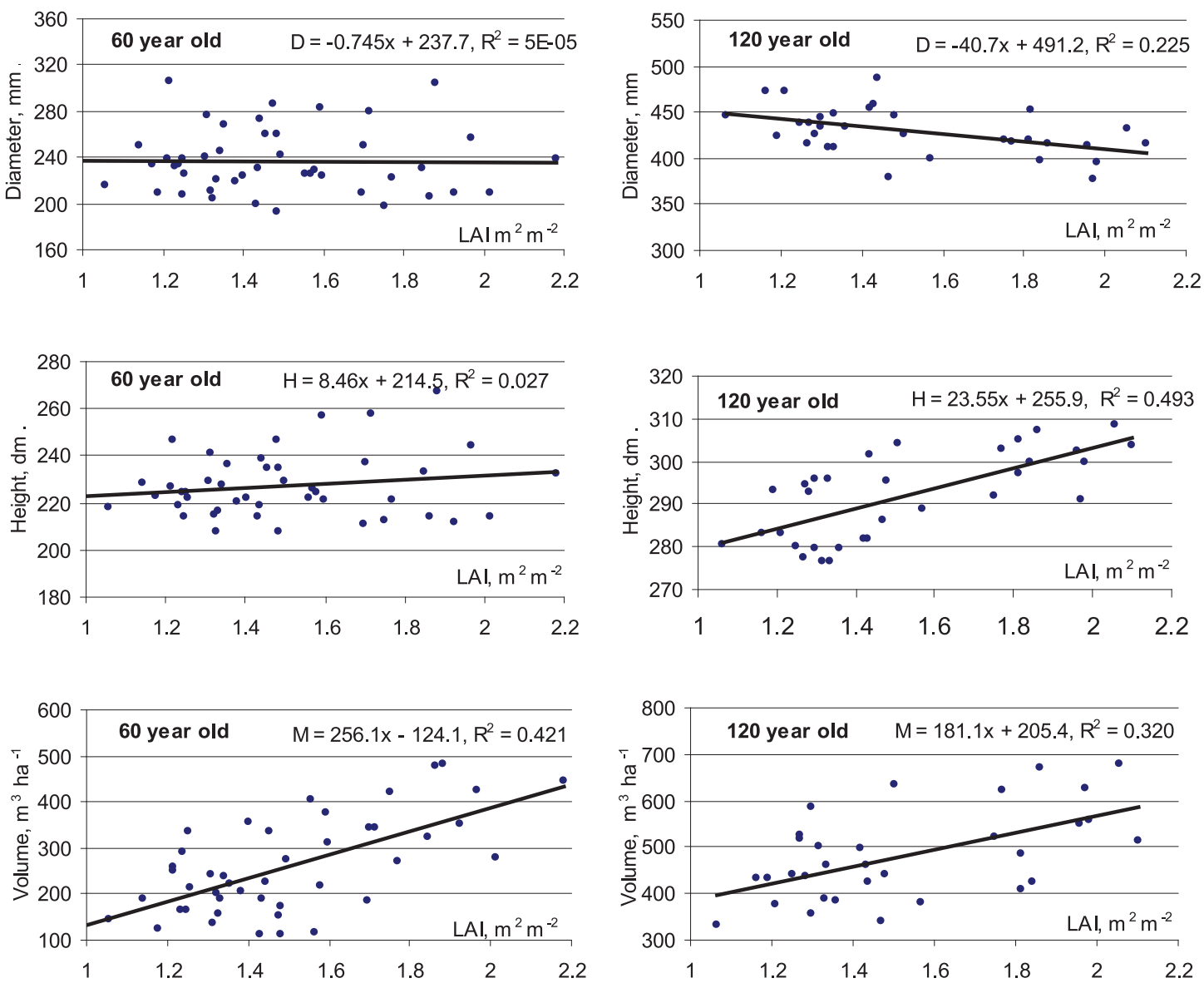

Figure 3. Relationship between LAI and main parameters of the monitored pine plots in two main age groups.

evergreen tree species (Pokorny and Stojnič, 2012; Thomas and Winner, 2000) and what confirm our data analyzing LAI of mixtured coniferous stands with dense understorey vegetation and samplings level.

Notwithstanding this, significant relationships were detected between mean values of stands LAI and cover intensity of shrubs, grass and moss levels. It is the main parameters investigating reaction of forest ecosystem to the effect of nitrogen critical loads (Holmberg et al., 2012). In stands with closured tree canopy, which is characterized by high level of LAI, the cover of understudy vegetation is usually significantly lower than in stands with more open canopy. Indirect relationships between cover intensity of grasses and mosses indicated that higher LAI reduce light intensity under tree canopy, resulting in

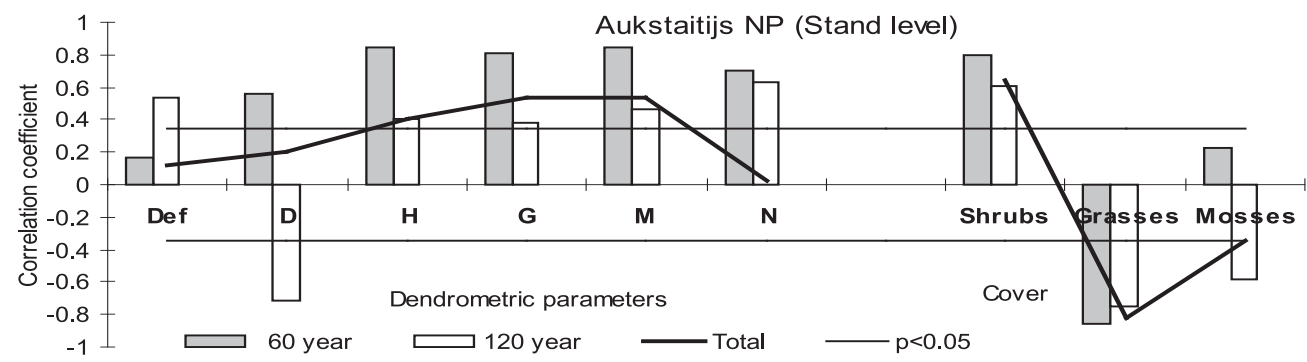

Figure 4. Relationships between LAI and dendrometric parameters, defoliation and cover intensity of understorey vegetation of pore pine stands. 
decreasing abundance and species composition of herbaceous and moss species (Figure 4). This data well agree with data obtained in mixture coniferous stands at Aukstaitijs IMS.

Uncertainties in this study made only the results obtained from correlative analysis between tree crown defoliation and LAI on both level, i.e., on Aukstaitija IMS (single plots) and Aukstaitija NP (averaged to stand) data level. A lot of studies are dedicated to use the LAI estimated by indirect methods for the stand health analysis (Pokorny and Stojnič, 2012). Some authors claim that mass attacks of the European pine sawfly Neodiprion sertiferon on Scots pine (Pinus silvestris L.) forest in Norway in 2005 (Solberg et al. 2006) demonstrated that the defoliation could be mapped by repeated ALS scans. Later, it was found that the insect damage could also be mapped with MODIS satellite data, using the ALS data for ground truthing (Eklundh et al. 2009). However, as indicated by Solberg et al. (2006), the canopy penetration and the corresponding LAI were derived only from the first echo of each pulse, i.e. from the fraction of the first echoes located below the canopy. This penetration rate might represent an underestimation of gap fraction, and hence an underestimation of the defoliation, because the footprint size of a laser pulse which might be too large to produce first echoes after penetrating down small canopy gaps produced by defoliating insectlarvae (Morsdorf et al., 2006). Nonetheless, this direct relationship between mean tree crown defoliation level and LAI were detected. Relationships between stand dendrometric parameters and mean value of defoliation in this age group revealed the increase of defoliation with increase in tree stem diameter, height and volume. These findings were in full agreement with the statement that condition of older stands is frequently worse than that of the younger ones. Such interaction was more significant than the relationship between LAI and crown defoliation (Augustaitis et al., 2009; Augustaitis, 2011; Mozgeris et al., 2011b). Insufficient differences between mean values of defoliation (mean value of defoliation fluctuated between $16 \%$ and $26 \%$ ) as well as a very high location of pine crown and significant part of stem and branches in hemispheric photography could be attributed to key factors of such kind of relationships.

Comparison of indirectly and semi-directly estimated LAI. To detect real effect of needles on detected LAI by HemiView system, we attempted to compare the tree LAI detected by the indirect method using hemispheric photographs with LAI detected by semi-direct method, using long term data on litterfall during September - October. Even over this period litterfall is mainly structured from pine needles. Due to the fact that in November in pine crown are left only the needles of the age of two years, their amount also should be two times bigger than litterfall amount. Surface area of such amount of needles should best reflect LAI of pine trees growing around. Presented data confirm this our consumption (Figure 5) as well as litterfall mass over this period (Figure 6). The evidence that there was no clear general relationship between the annual amount of litterfall and hemispherical photographs estimates LAI other authors explained mainly by the heterogeneity of the canopy, or to biased litterfall collection at sites on steep slopes or sites subject to strong winds (Thimonier et al., 2010). In our case these well-known factors did not have a significant effect on litterfall amount and therefore using detected coefficient of transformation of the needles mass to area, we detected LAI of pine trees growing around litter samplers. Hemispherical photographs combined with litter collection are quite often applied to improve reliability of LAI detected by indirect methods. (Qi et al., 2013) state that even LAI detected by HemiView system in November is corrected for contribution of woody material and clumping at shoot and beyond shoot levels, to give minimum "true" LAI, which is detected based on litterfall (Qi et al., 2013). Based on it, we can conclude that LAI estimated using hemispheric photography significant reflects "true" pine needles LAI. Higher values of indirectly estimated LAI could be attributed to stem and branches area, which are also included into the LAI value calculation. It explains why most of the scientists suggest calling the parameter estimated by indirect methods as plants are index (PAI) especially if no correction for woody material is employed (Smith et al., 2008).

Finally, investigating sustainability of forest and its adaptive capacity, mitigating negative effects of climate change, balance of nutritional sources including carbon sequestration become the greatest concern (Paoletti et al., 2003). One of the key variables of mass balance in forest ecosystem is litterfall amount. Our earlier findings revealed that litterfall amount during August-October months significantly reflect changes in total annual litterfall amount (Figure 7). Correlative analysis revealed that increasing in LAI by $1 \mathrm{~m}^{2} \mathrm{~m}^{-2}$ increase litterfall by approximately $1 \mathrm{t}$ per ha during August-October months (Figure 8). Based on detected relationships between litter amount during August-October and annual litter amount, we can conclude that $1 \mathrm{~m}^{2} \mathrm{~m}^{-2}$ LAI increase annual amount of litter up to $1.7 \mathrm{t} \mathrm{ha}^{-1}$ in matured and over matured pure pine stands. 


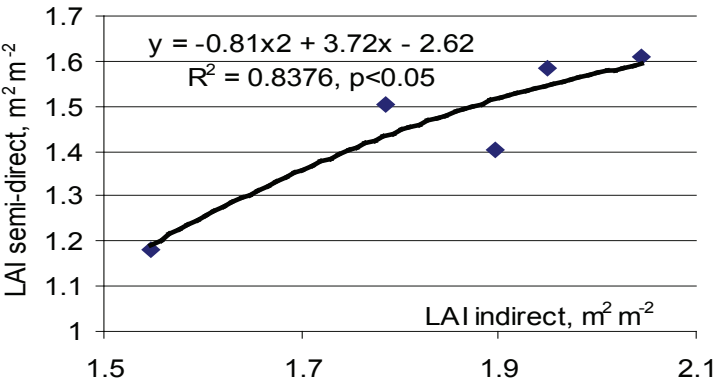

Figure 5. Relationship between LAI indices estimated by semi-direct and indirect methods.

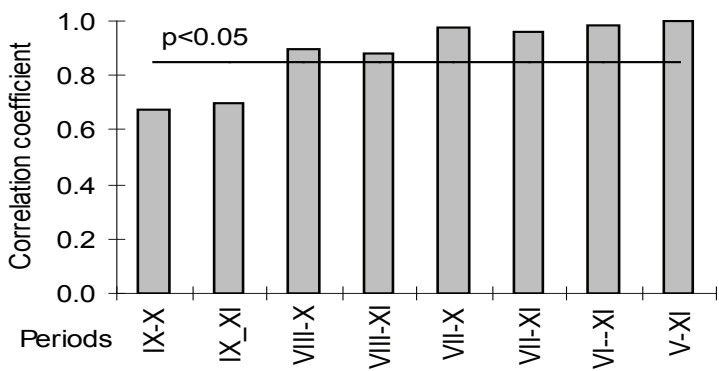

Figure 7. Relationship between annual litter mass. and litterfall amount of different periods.

\section{Conclusion}

The obtained data revealed that the use of hemispheric photography for LAI estimation in multi-aged and multi-layered mature and over mature pine and spruce stands is rather problematic.

Only cover intensity of understory vegetation - grasses and mosses - was reflected best. In pure even-aged pine stands LAI reflected spatial changes in main dendrometric stand parameters as well as in cover intensity of shrubs, grasses and mosses levels well.

Significant relationship was detected between LAI and pine needles litterfall in September-October that allowed to detect that LAI increase by $1 \mathrm{~m}^{2} \mathrm{~m}^{-2}$ increased the total annual litterfall amount by $1.7 \mathrm{tha}^{-1}$.

\section{References}

1. Anderson, M.C. (1964). Studies of the woodland light climate I. The photographic computation of light condition. Journal of Ecology, 52, pp. 27-41.

2. Arias, D., Calvo-Alvarado, J., Dohrenbusch, A. (2007). Calibration of LAI-2000 to estimate

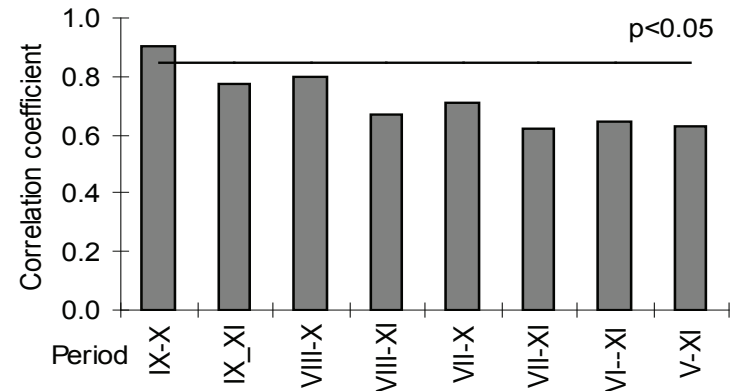

Figure 6. Interaction of indirectly estimated LAI and litterfall amount over different period.

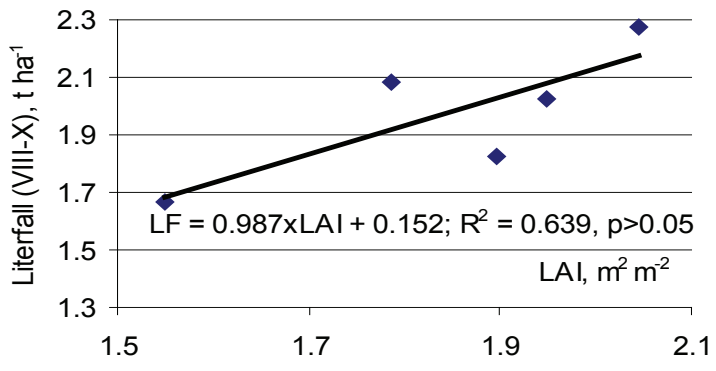

Figure 8. Dependency of litter mass on tree. LAI of pine stand

leaf area index (LAI) and assessment of its relationship with stand productivity in six native and introduced tree species in Costa Rica. Forest Ecology and Management, 247, pp. 185-193.

3. Augustaitis, A., Mozgeris, G., Eigirdas, M., Sajonas, M. (2009). Color Infrared Aerial Images to Evaluate Tree Crown Defoliation. Rural development 2009: the fourth international scientific conference, 15-17 October, 2009, Akademija, Kaunas region, Lithuania: proceedings. 4, pp. 213-216.

4. Augustaitis, A. (2011). Impact of Meteorological Parameters on Responses of Pine Crown Condition to Acid Deposition at Aukštaitija National Park. Baltic Forestry, 17, pp. 205-214.

5. Augustaitis, A., Augustaitienè, I., Kliučius, A., Pivoras, G., Šopauskienė, D., Girgždienė, R. (2010a). The seasonal variability of air pollution effects on pine conditions under changing climates. European Journal of Forest Research, 129, pp. 431-441.

6. Augustaitis, A., Šopauskienè, D.; Baužienè, I. (2010b). Direct and Indirect Effects of Regional 
Air Pollution on Tree Crown Defoliation. Baltic Forestry, 16, pp. 23-34.

7. Augustaitis, A., Bytnerowicz, A., Paoletti, E. (2014). Biological reactions of forests to climate change and air pollution. Environmental Pollution, 184, pp. 657-658.

8. Bringmark, L., Lundin, L., Augustaitis, A., Beudert, B., Dieffenbach -Fries, H., Dirnböck, T., Grabner, M.Th., Hutchins, M., Kram, P., Lyulko, I., Ruoho-Airola, T., Váňa, M. (2012). Trace Metal Budgets for Forested Catchments in Europe- $\mathrm{Pb}, \mathrm{Cd}, \mathrm{Hg}, \mathrm{Cu}$ and $\mathrm{Zn}$. Water Air and Soil Pollution, 224, pp. 1502-1-14.

9. Breda, N.J. (2003). Ground-based measurements of leaf area index: a review of methods, instruments and current controversies. Journal of Experimental Botany, 54, pp. 2403-2417.

10. Chianucci, F., Cutini, A. (2012). Digital hemispherical photography for estimating forest canopy properties: current controversies and opportunities. iForest, 5, pp. 290-295.

11. Chen, M.J., Rich, M.P., Gower, T., Norman, M.J., Plummer, S. (1997). Leaf area index of borel forests: Theory, techniques and measurements. Journal of Geophysical Research: Atmospheres, pp. 29429-29443.

12. Eklundh, L., Johansson, T. and Solberg, S. (2009). Mapping insect defoliation in Scots pine with MODIS time-series data. Remote Sensing of Environment, 113, pp. 1566-1573.

13. Evans, G.D., Coombe, D.E. (1959). Hemispherical and woodland canopy photography and the light climate. Journal of Ecology, 47, pp. 103-113.

14. Holmberg, M., Vuorenmaaa, J., Poschb, M., Forsius, M., Lundin, L., Kleemola, S., Augustaitis, A., Beudert, B., Wit, H.A. de; Dirnböck, T., Evansh, C.D., Frey, J., Grandin, U., Indriksone, I., Krám, P., Pompei, E., SchulteBisping, H., Srybny, A., Váňa, M. (2012). Relationship between critical load exceedances and empirical impact indicators at Integrated Monitoring sites across Europe. Ecological Indicators, 24, pp. 256-265.

15. Jonckheere, I., Fleck, S., Nackaerts, K., Muys, B., Copin, P., Weiss, M., Baret, F. (2004). Review of methods for in situ leaf area index determination: Part I. Theories, sensor and hemispherical photography. Agricultural and Forest Meteorology, 121 (1-2), pp. 19-35

16. Marozas, V., Augustaitis, A., Armolaitis, K., Kliučius, A., Pilkauskas, M. (2014). Effects of planted European beech on the understory in Scots pine forests of Lithuania. iForest, 7, pp. 12-18.
17. Morsdorf, F., Kotz, B., Meier, E., Itten, K., Allgower, B. (2006). Estimation of LAI and fractional cover from small footprint airborne laser scanning data based on gap fraction. Remote Sensing of Environment, 104, pp. 50-61.

18. Mozgeris, D., Augustaitis, A., Augustaitienè, I., Mozgeris, G., Makūnas, T. (2011a). Effect of Rapidly Changing Meteorological Parameters on Over-matured Scots Pine Tree Growth in Aukštaitija National Park. Rural development 2011: the fifth international scientific conference, 24-25 November, 2011, Akademija: proceedings. 5, pp. 98-102.

19. Mozgeris, G., Augustaitis, A., Gečionis, A. (2011b). Small Format Aerial Images to Estimate the Pine Crown Defoliation. Rural development 2011: the fifth international scientific conference, 24-25 November, 2011, Akademija: proceedings. 5 , pp. 452-458.

20. Norman, J.M., Campbell, G.S. (1989). Canopy structure. In: Pearcy R.W., Ehlringer J., Mooney H.A., Rundel P.W. (Eds.), Plant Ecology: Field Methods and Instrumentation. Chapman and Hall, London, pp. 301-325.

21. Paoletti, E., Augustaitis, A., Bytnerowicz, A., Bucher, J., Ferretti, M., Johnson, D., Karnosky, D., Mankovska, B., Muller - Starck, G., Percy, K. (2003). State of science and knowledge gaps with respect to air pollution impacts on forests. Ekologia, 22, pp. 8-17.

22. Pociene L., Augustaitis A., Augustaitiene I., Kliučius A., Pivoras G. (2011). Effect of Meteorological Parameters on Scots Pine Crown Condition in Aukstaitija National Park. Rural development 2011: the fifth international scientific conference, 24-25 November, 2011, Akademija: proceedings. 5, pp. 111-116.

23. Pokorny, R., Stojnič, S. (2012). Leaf area index of Norway spruce stand in relation to its age and defolation. Beskydy, 5 (2), pp. 173-180.

24. Rich, P.M. (1990). Characterizing plant canopies with hemispherical photographs. Remote sensing Reviews, 5 (1), pp. 13-29.

25. Qi, Y., Jin, G., Liu, Z. (2013). Optical and litter collection methods for measuring leaf area index in an old-growth temperate forest in northeastern China. Journal of Forest Research. 18, pp 430439.

26. Ryu, Y., Sonnentag, O., Nilson, T., Vargas, R., Kobayashi, H., Wenk, R., Baldocchi, D.D. (2010). How to quantify tree leaf area index in an open savanna ecosystem: A multi-instrument and multi-model approach. Agricultural and Forest Meteorology, 150, pp. 63-76. 
27. Sampson, D.A., Allen, H.L. (1995). Direct and indirect estimates of Leaf Area Index (LAI) for lodgepole and loblolly pine stands. Tree, $9 \mathrm{pp}$. 119-122.

28. Smith, M.L., Anderson, J., Fladeland, M. (2008). Forest Canopy Structural Properties in C.M. Hoover (ed.) Field Measurements for Forest Carbon Monitoring, (C) Springer Science + Business Media B.V., pp. 179-196.

29. Solberg, S., Naessset, E., Hanssen, K.H. and Christiansen, E. (2006). Mapping defoliation during a severe insect attack on Scots pine using airborne laser scanning. Remote Sensing of Environment, 102, pp. 364-376.
30. Thomas, S.C., Winner, W.E. (2000). Leaf area index of an old-growth Douglas-fir forest estimated from direct structural measurements in the canopy. Canadian Journal of Forest Research, 30(12), pp. 1922-1930.

31. Thimonier, A., Sedivy, I., Schleppi, P. (2010). Estimating leaf area index in different types of mature forest stands in Switzerland: a comparison of methods. European Journal of Forest Research, 129, pp 543-562.

32. UN-ECE. (1994). Manual on methods and Criteria for Harmonised Sampling, Assessment, Monitoring and Analysis of the Effects of Air Pollution on Forests. ICP, $178 \mathrm{p}$.

\section{Acknowledgement}

The study was carried out within the framework of the national project No VP1-3.1-ك̌MM-08-K-01-025 entitled "Specific, genetic diversity and sustainable development of Scots pine forest to mitigate the negative effects of increased human pressure and climate change" supported by the EU structural funds and administered by the Lithuanian Ministry of Science and Education. 